\title{
Parts-Per-Million (Salen)Fe(III) Homogeneous Catalysts for the Production of Biodiesel from Waste Cooking Oils
}

\author{
Massimo Melchiorre ${ }^{1,2}$. Angela Amoresano ${ }^{1}$ Peter H. M. Budzelaar ${ }^{1}$. Maria E. Cucciolito ${ }^{1,3}$ • Fabio Mocerino ${ }^{1}$. \\ Gabriella Pinto ${ }^{1} \cdot$ Francesco Ruffo $^{1,3} \cdot$ Angela Tuzi $^{1} \cdot$ Roberto Esposito $^{1,3}$ (D)
}

Received: 16 September 2021 / Accepted: 31 January 2022 / Published online: 19 February 2022

(C) The Author(s) 2022

\section{Abstract}

This work describes the application of a library of iron(III)-salen catalysts in the production of biodiesel from vegetable oils. The conversion of neutral soybean oil is complete within two hours at $160-180^{\circ} \mathrm{C}$ with low catalyst loading $(0.10 \mathrm{~mol} \%)$. A comparative screening reveals that the catalysts containing acetate as a fifth ligand are the most performing, and these have been conveniently used to convert acidic and waste cooking oils (WCO). WCOs were used as received without further purification to produce biodiesel in high yield (85-90\%) under optimized conditions $\left(2 \mathrm{~h}\right.$ at $180{ }^{\circ} \mathrm{C}$, catalyst loading $0.1 \mathrm{~mol} \%$, oil to alcohol molar ratio 1:20). The iron content in the lipophilic and hydrophilic phases of the crude mixture was investigated and the residual concentration in biodiesel was found to be in the order of 10-14 ppm, comparable to that contained in biodiesels from other sources.

\section{Graphical Abstract}

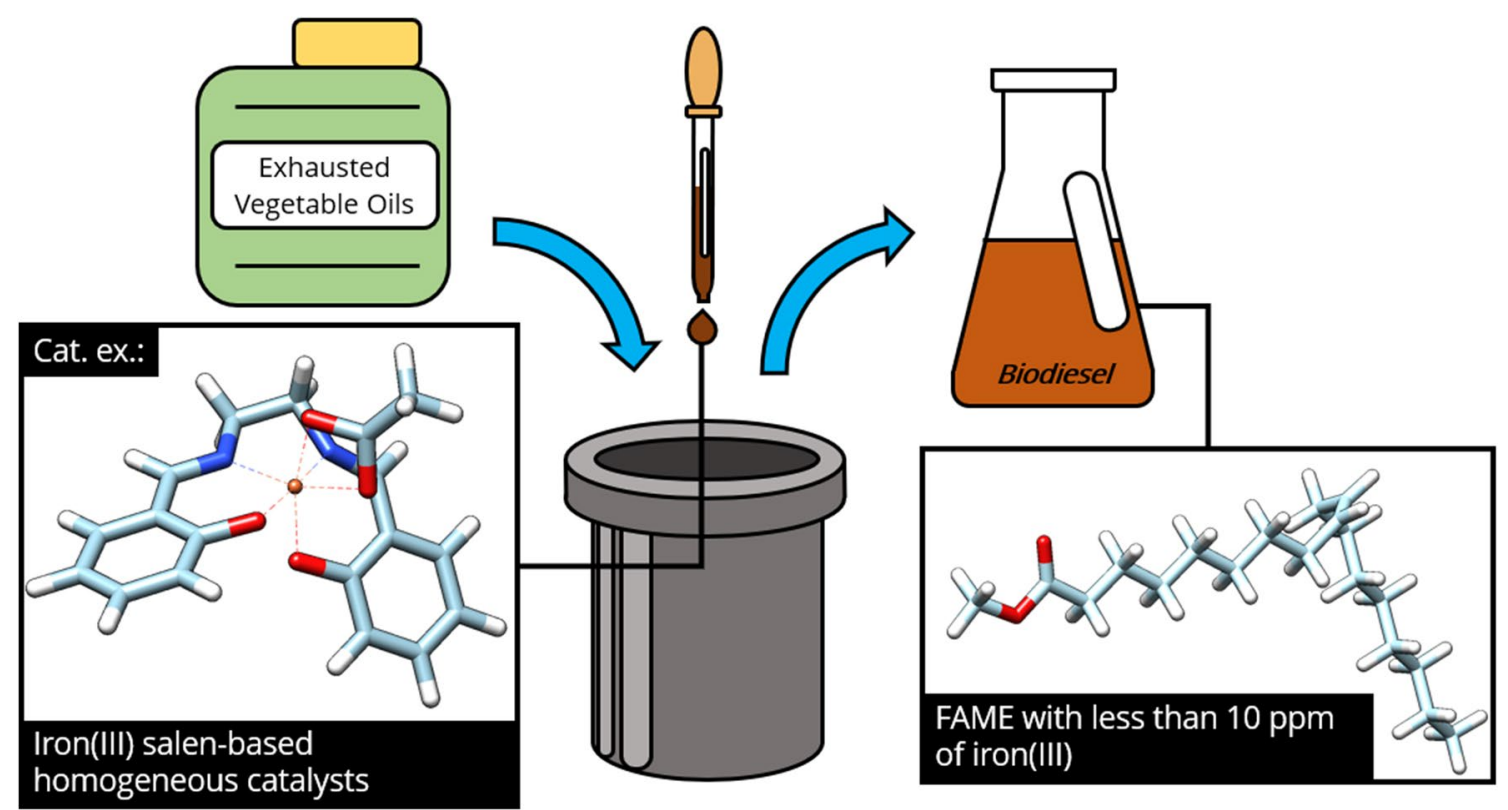

Keywords Iron(iii) · Salen ligands · Esterification · Transesterification · Biodiesel · Homogeneous catalysis · Waste cooking oils

Roberto Esposito

roberto.esposito@unina.it

Extended author information available on the last page of the article 


\section{Introduction}

Current social, economic and industrial developments push towards a shift from fossil energy sources and carriers to renewable ones [1]. In this context, the production of biofuels occupies a relevant sector of production [2,3], its manufacture having reached 165 billion litres in 2019 [4]. The synthesis of biodiesel involves transesterification of vegetable oils with light alcohols, to obtain a mixture of fatty acid alkyl esters (biodiesel) and glycerol useful for further uses [5-7] (Scheme 1)

The use of edible vegetable oils for biodiesel production raises ethical issues due to competition with human consumption, while the use of non-edible crops can result in competition for arable land. The use of waste cooking oil (WCO) [8-13] suffers from no such issues and is actually perfectly aligned with the UN guidelines of re-cycle and re-use [14]. Of course, the use of WCO is not without its problems. The most effective transesterification catalysts are strongly basic and are easily deactivated by the presence of significant amounts of free fatty acids (FFA, often between 2 and 5\% in WCO) [15]. The traditional solution is the use of an extra (acid-catalyzed) esterification step preceding the base-catalyzed transesterification, but the additional process steps (acid treatment and washing) reflect negatively on the sustainability of the biodiesel production. [16].

One possible alternative is the use of a Lewis-acidic catalyst that combines activity in esterification and transesterification, allowing biodiesel formation in a single process step [17-19]. Transition metals are often used in Lewis-acid catalysis. However, many of them are toxic, very expensive and not equally distributed on the globe, raising ethic problems due to their exploitation. While the use of these metals can be necessary in fine chemistry, such as in the pharmaceutical industry, their use for more basic chemistry is unsustainable. Thus, metals with low cost, convenient availability and favourable ecotoxicological profile stand out. Among them, iron and zinc are particularly suitable given their outstanding properties and the sustainability advantages they offer $[20,21]$. Iron has been already used in transesterification reactions [22]. Some heterogeneous catalysts containing iron also showed good activity in biodieselformation reaction but, apart from the few examples [23, 24], the use of this metal in biodiesel production is still little explored. This is especially true in homogeneous catalysis.

While heterogeneous catalysts require a simple workup for their re-cycle, they often have associated problems, such as low activity (high loading required) and leaching

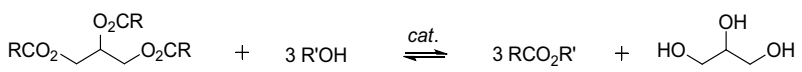

Scheme 1 The synthesis of biodiesel (recovery step required) that reduce their attractiveness. On the contrary, homogeneous catalysts have the advantages of providing a high activity and a simpler understanding and control of their reaction mechanism. At the same time, removing the catalyst can be more difficult. However, if exceptionally active, the catalysts can be left in the product since the impurity caused by them can be acceptable for its application. Following our studies concerning valorisation of vegetable feedstock [20-22, 25-27], the present work sketches how-paradoxicallyuse of a homogeneous acidic catalyst might be the preferred solution. In this paper a family of homogeneous Lewis acids catalysts based on iron(III) complexes has been prepared and tested in the transesterification of fresh vegetable oils and waste cooking oils. Under optimized conditions, the catalysts are active in very diluted concentration, and leave an iron content inside the final product compatible with its application, thus making its removal unnecessary.

\section{Material and Methods}

\subsection{General}

rac-1,2-cyclohexanediamine, ethylenediamine, salicylaldehyde, 3-methylsalicylaldehyde, triethylamine, iron(III) chloride hexahydrate, anhydrous iron(II) acetate, inorganic acids and the solvents were purchased from Merck KGaA, Darmstadt, (Germany) and used as received without further purification. Determination of free fatty acids (FFAs) was performed in accordance with European regulation (EU) 2016/1227-Annex 2 (Determination of free fatty acids, cold method) [28], simulated acidic soybean oil was prepared by adding the appropriate amount of oleic acid (Carlo Erba, $90 \%$ ) to the fresh soybean oil to achieve the appropriate acidity: to prepare $100 \mathrm{~g}$ of acidified soybean oil (AV $\left.2.8 \mathrm{mg}_{\mathrm{KOH}} / \mathrm{g}_{\mathrm{oil}}\right)$ from fresh soybean oil (AV $\left.0.1 \mathrm{mg}_{\mathrm{KOH}} / \mathrm{g}_{\mathrm{oil}}\right)$, $98.64 \mathrm{~g}$ of oil were combined with $1.36 \mathrm{~g}$ of oleic acid. Final acidity was verified by the titration method previously mentioned. NMR spectra were recorded with a Bruker Avance Ultrashield 400 (Bruker Corporation, Billerica, Massachusetts, US) operating at proton frequency of $400 \mathrm{MHz}$ or with a Varian 500 Oxford (Varian Inc., Palo Alto, California, US) at proton frequency of $500 \mathrm{MHz}$. High-resolution mass spectrometry (HRMS) spectra were recorded with Xevo® G2-S QTof (Waters, Milford, Massachusetts, US) mass spectrometer in positive mode. IR spectra were recorded on a JASCO FT/IR-430 spectrophotometer (JASCO EUROPE, Cremella, Italy). UV-Vis spectra were recorded on a JASCO V-750 spectrophotometer (JASCO EUROPE, Cremella, Italy). The reactions were performed in a Low-Pressure Parr Reactor model 5100 equipped with MI-heating band purchased from 
Watlow Italy s.r.l. (Italy). Ligand rac- $N, N^{\prime}$-bis(salicylidene)1,2-cyclohexanediamine [29], complexes 1 [22, 30-32], 2 [33], 3 [34], 4 [35], 6 [36] and iron(III) acetate (included for comparison) [37] were prepared according to literature methods. The exhausted oil WCO2 was provided by "Little Food", Bagnoli (Napoli, Italy).

\subsection{Synthesis of Complex 5}

A mixture of $r a c-N, N^{\prime}$-bis(salicylidene)-1,2cyclohexanediamine $(1.0 \mathrm{~g}, 3.2 \mathrm{mmol})$ and iron(II) acetate $(0.53 \mathrm{~g}, 3.0 \mathrm{mmol})$ were stirred $24 \mathrm{~h}$ at room temperature in $40 \mathrm{~mL}$ of acetone. The dark red precipitate was then filtered and washed with acetone (yield: $0.98 \mathrm{~g}, 75 \%$ ). IR spectrum (nujol mull, Figure S1): $1616 \mathrm{~cm}^{-1}(\mathrm{C}=\mathrm{N}) ; 1465 \mathrm{~cm}^{-1}$ (C=O, acetate). Mp $340{ }^{\circ} \mathrm{C}$ (with decomposition). HRMS (ESI/QTOF): $\mathrm{m} / \mathrm{z}\left[\mathrm{C}_{20} \mathrm{H}_{20} \mathrm{FeN}_{2} \mathrm{O}_{2}\right]^{+}=376.0869 \mathrm{calcd}$, $\mathrm{m} / \mathrm{z}=376.08720$ found (Figure $\mathrm{S} 2$ ). UV-Vis spectrum in methanol: $\Lambda_{\max } 232 \mathrm{~nm}$ (Figure S3).

\subsection{Catalytic Runs}

A typical example of catalysis is as follows: $90 \mathrm{~g}$ of oil (ca. $0.1 \mathrm{~mol}), 32 \mathrm{~g}$ of methanol $(1.0 \mathrm{~mol})$ and $1.0 \times 10^{-4} \mathrm{~mol}$ $\left(0.5 \times 10^{-4} \mathrm{~mol}\right.$ or $\left.0.25 \times 10^{-4} \mathrm{~mol}\right)$ of catalyst $\left(\mathrm{mol}_{\mathrm{Fe}}\right.$ versus mol $_{\text {oil }}$ equal to $0.10 \%, 0.050 \%$ or $0.025 \%$ ) were placed in the stainless steel reactor vessel (Fig. 1).

The temperature was raised to the desired temperature $\left(160\right.$ or $180^{\circ} \mathrm{C}$, through the heating band) and kept at this value for the appropriate time. The pressure naturally increased due to the vapor pressure of the components (mainly due to methanol) reaching values in the range of 14-24 bar, depending on the temperature $\left(160-180{ }^{\circ} \mathrm{C}\right)$ (WARNING! The reactor vessel must be sealed and shielded properly; overpressure risks may occur). At the end of

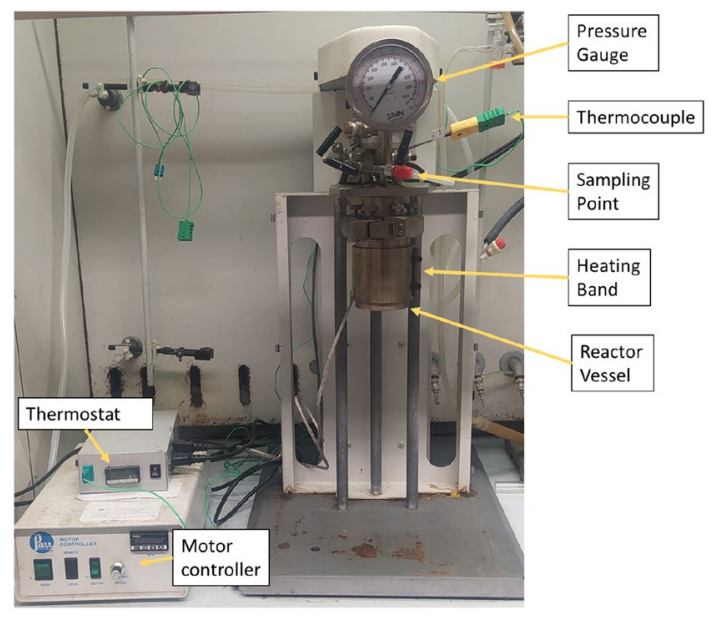

Fig. 1 The Parr reactor used for catalysis reaction, the heating band was turned off and removed. Then the vessel was rapidly cooled in an ice bath. The reaction mixture was evaporated under vacuum to remove excess methanol. The resulting oily fraction was analysed via ${ }^{1} \mathrm{H}$ NMR spectroscopy to determine the yield of the reaction (as reported in paragraph S1 and Figure S4).

\subsection{X-Ray Crystal Structure Analysis}

Single crystals of complex $\mathbf{5}$ suitable for X-ray structure analysis were obtained by slow evaporation of chloroform/ heptane. Diffraction data were collected at low temperature ( $173 \mathrm{~K}$ flux of $\mathrm{N}_{2}$ ) with a Bruker-Nonius KappaCCD diffractometer (MoK $\alpha$ radiation). Standard procedures were used to solve and refine the structure (SIR97 program [38] and SHELXL-2018/3 [39] program). See Supporting Information for details. Programs ORTEP-3 [40] and Mercury CSD 4.0 were used for figures [41]. CCDC 2094779

\subsection{ICP-MS Analysis}

Inductively Coupled Plasma-Mass Spectrometry (ICPMS) analysis was performed for determination of iron concentrations in the two phases of the reaction mixture. Before the analysis, samples $(0.1 \mathrm{~g})$ were mineralized by adding a mixture of $69 \%$ nitric acid and $37 \% \mathrm{v} / \mathrm{v}$ hydrochloric acid in 3:1 ratio and incubated overnight at $95{ }^{\circ} \mathrm{C}$ by using a ReactiTherm ${ }^{\mathrm{TM}}$ system. The mineralized samples were recovered with ultrapure water and filtered using $0.45 \mu \mathrm{m}$ filters. A proper dilution of each sample was made before introducing them to the plasma.

Measurements were performed on an Agilent 7700 ICP-MS instrument (Agilent Technologies Santa Clara, California, US) equipped with a frequency-matching radio frequency (RF) generator and 3rd generation Octapole Reaction System (ORS3) operating with helium gas in ORF. The following parameters were used: RF power: $1550 \mathrm{~W}$, plasma gas flow: $14 \mathrm{~L} \mathrm{~min}^{-1}$; carrier gas flow: $0.99 \mathrm{~L} \mathrm{~min}^{-1}$; He gas flow: $4.3 \mathrm{~mL} \mathrm{~min}{ }^{-1},{ }^{103} \mathrm{Rh}$ isotope was used as an internal standard (final concentration: $50 \mu \mathrm{g} \mathrm{L}^{-1}$ ). Standard solutions (ICP multi-element standard solution IV, TraceCERT, Merck) were prepared in 3\% nitric acid at five different concentrations $\left(0,1,10,50\right.$, and $\left.100 \mu \mathrm{g} \mathrm{L}^{-1}\right)$. Iron concentrations were measured in triplicate.

\section{Results and Discussion}

The starting point for this study was the observation of the high transesterification activity [42] by the dinuclear Fe(III)salen complex 1 (Fig. 2), an oxo-bridged dimeric species showing cooperative effects in catalysis as often observed for dinuclear iron complexes [43], which already proved to 


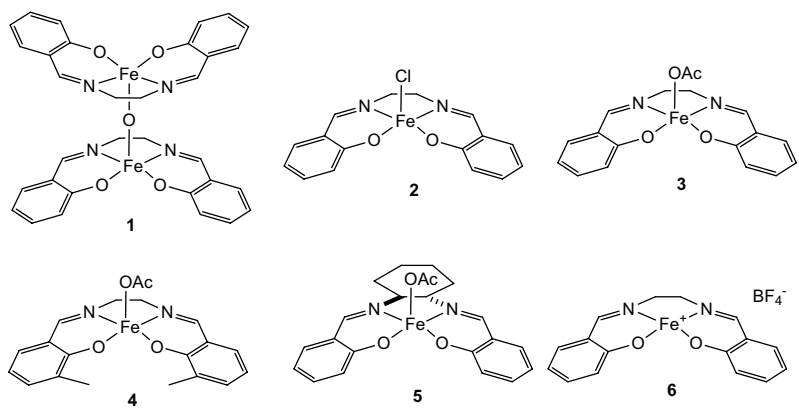

Fig. 2 Salen complexes used as catalysts

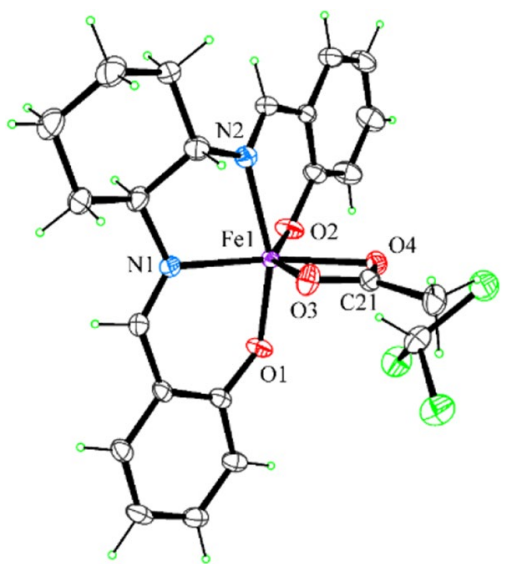

Fig. 3 ORTEP projection of $\mathbf{5}$ together with the crystallization solvent molecule $\mathrm{CHCl}_{3}$. Thermal ellipsoids are drawn at $30 \%$ probability of the electron density. Only the predominant disordered parts of the structure have been reported in the drawing for clarity. Selected bond distances and angles: $\mathrm{Fe} 1-\mathrm{N} 1=2.106(4)$, $\mathrm{Fe} 1-\mathrm{N} 2=2.087(4), \quad \mathrm{Fe} 1-\mathrm{O} 1=1.889(3), \mathrm{Fe} 1-\mathrm{O} 2=1.895(3), \mathrm{Fe} 1-$ $\mathrm{O} 3=2.128(3), \quad \mathrm{Fe} 1-\mathrm{O} 4=2.084(3) \quad \AA ; \quad \mathrm{O} 1-\mathrm{Fe} 1-\mathrm{N} 2=158.46(15)$, $\mathrm{N} 1-\mathrm{Fe} 1-\mathrm{O} 2=124.91(13), \mathrm{C} 21 \cdots \mathrm{Fe} 1-\mathrm{O} 2=119.02(14), \quad \mathrm{C} 21 \cdots \mathrm{Fe} 1-$ $\mathrm{N} 1=115.58(15)^{\circ}$

be a good catalyst for the transesterification and esterification of levulinic acid [22]. Salen ligands are easy to synthesize from inexpensive starting materials, allow modular construction, and are highly tunable in stereoelectronic properties. Options are available for attaching them to a support [44]. Iron(III) complexes are easy to handle, being stable to air and moisture. Preliminary experiments indicated that the dinuclear nature of $\mathbf{1}$ is not relevant to its transesterification activity. With this in mind, complexes 1-6 were tested, covering variations of the counterion $(\mathbf{2}, \mathbf{3}, \mathbf{6})$, steric hindrance (4) and skeletal variation (5).

The molecular structure of complex $\mathbf{5}$ is shown in Fig. 3 (Figures S5-S7 show other views). The compound crystallizes in the space group $\mathrm{P} 2{ }_{1} / \mathrm{c}$ with a molecule of complex and a chloroform solvent molecule in the independent unit. Both the chloroform molecule and the acetate group are disordered over two positions (major:minor ratio of 0.89:0.11). All bond distances are in the range of values found for similar $\mathrm{Fe}\left(\mathrm{N}, \mathrm{N}^{\prime}, \mathrm{O}, \mathrm{O}^{\prime}\right)(\mathrm{OAc}) \mathrm{com}$ plexes (Table S2) [34]. In many (salen) $\mathrm{MX}_{2}$ complexes the salen ligand assumes a mer-mer configuration, with the two monodentate $\mathrm{X}$ ligands occupying the remaining apical positions (i.e. mutually trans); this is also observed in the polymeric structure of (salen) $\mathrm{Fe}\left(\mu_{2}\right.$-catena-OAc) [45]. In the more usual monomeric (salen)Fe( $\kappa^{2}-\mathrm{OOCR}$ ) complexes the natural preference of the salen ligand for mer-mer coordination conflicts with the bidentate nature of the carboxylate, leading to a highly deformed octahedral environment of the Fe ion. [34, 46-49].

This coordination mode is also seen in complex $\mathbf{5}$, showing that the cyclohexane ring does not affect the geometric preference in a major way. In any case, these structures demonstrate that (salen)Fe(III) complexes have two mutually cis coordination sites available during catalytic reactions. This might be relevant to (trans)esterification catalysis, since it has been argued that the role of the acidic catalyst in such reactions goes beyond that of simple Lewis acid and may involve more than a single carboxylate [50, 51].

Accordingly, a plausible mechanism for complexes 2-5, based on ref 50, is shown in Scheme 2. Initially a carbonyl oxygen of the triglyceride coordinates the metal center (II). The coordination enhances the electrophilicity of the carbonyl carbon that can undergo nucleophilic attack by methanol. This generates the tetrahedral intermediate III that can evolve into IV assisted by the vicinal carboxylate. The methyl ester and the diglyceride are thus obtained. The cycle can be repeated starting from diglyceride or monoglyceride as well.

A first catalytic screening was carried out on the entire set of catalysts using a neutral soybean oil. At the boiling temperature of methanol $\left(64{ }^{\circ} \mathrm{C}\right)$ the performance of the catalysts was not satisfactory. To reach high conversions in convenient time by improving the kinetics, a temperature of $160{ }^{\circ} \mathrm{C}$ was selected, and the reaction was therefore carried out in a closed batch reactor (Fig. 1) capable of withstanding the vapor pressure of methanol. Details of the reactor are given in the experimental section. In fact, at $160{ }^{\circ} \mathrm{C}$ adequate conversions to discriminate among the catalysts were obtained within $2 \mathrm{~h}$ with a low catalyst loading $(0.10 \mathrm{~mol} \%$ vs oil). At this temperature the endogenous pressure of the mixture reaches $14 \mathrm{bar}$, close to the theoretical vapour pressure of pure methanol. For this reason, the reactions were performed in a closed stainless steel batch reactor, equipped with a mechanical stirrer, a pressure gauge and a thermocouple (further details in experimental section). The methanol:oil ratio was varied from 4:1 (mol:mol, almost stoichiometric conditions) to 20:1. The results are collected in Table 1 and graphically represented in Fig. 4. 
Scheme 2 Proposed reaction pathway for transesterification

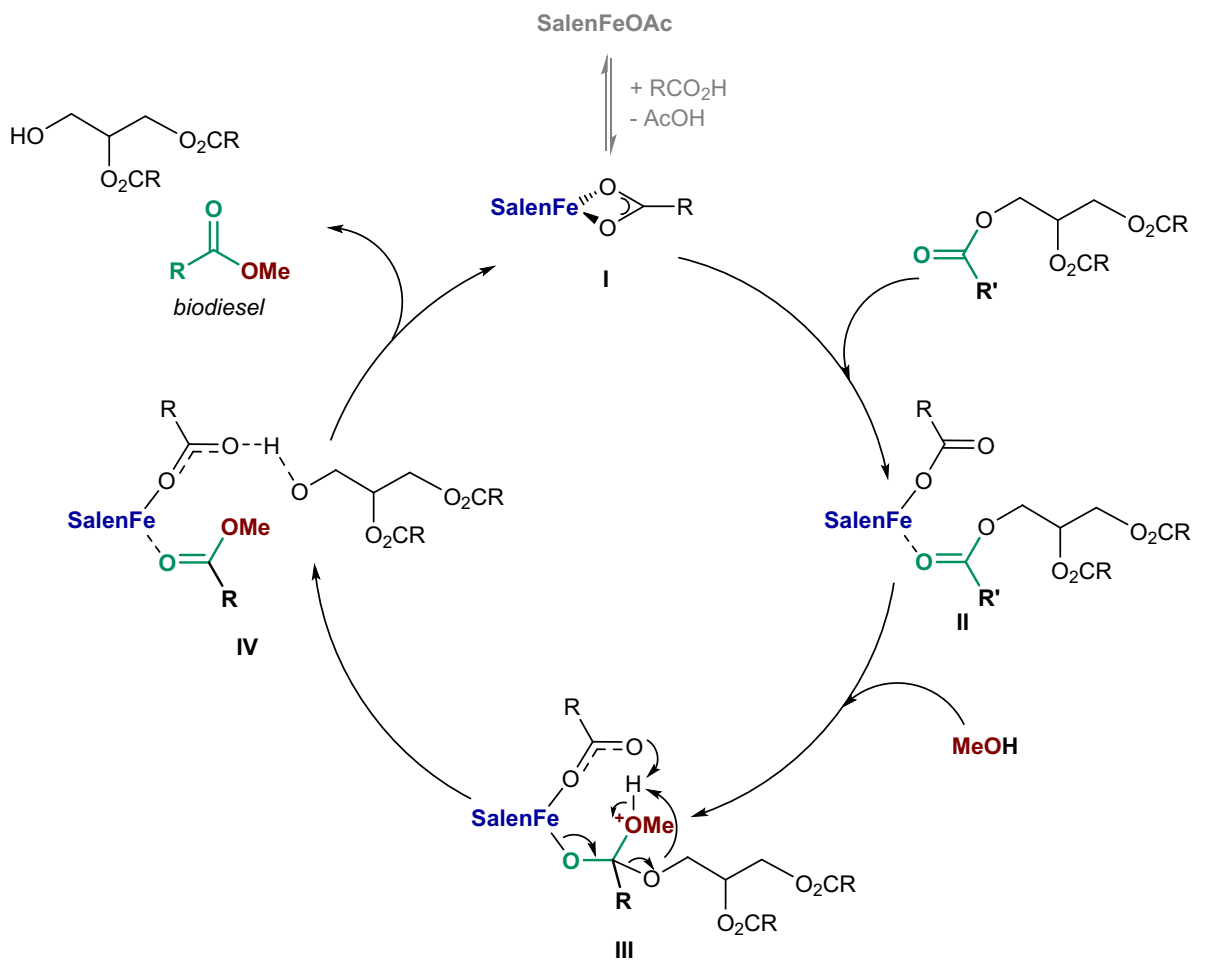

Table 1 Screening of the catalysts and of the molar ratio methanol:oil

\begin{tabular}{llll}
\hline Entry & Catalyst & $\begin{array}{l}\text { Methanol:oil ratio } \\
(\mathrm{mol}: \mathrm{mol})\end{array}$ & Yield $^{\mathrm{a}}(\%)$ \\
\hline 1 & $\mathbf{1}$ & $4: 1$ & 76 \\
2 & $\mathbf{2}$ & $4: 1$ & 66 \\
3 & $\mathbf{3}$ & $4: 1$ & 74 \\
4 & $\mathbf{4}$ & $4: 1$ & 71 \\
5 & $\mathbf{5}$ & $4: 1$ & 76 \\
6 & $\mathbf{1}$ & $10: 1$ & 98 \\
7 & $\mathbf{2}$ & $10: 1$ & 80 \\
8 & $\mathbf{3}$ & $10: 1$ & 97 \\
9 & $\mathbf{4}$ & $10: 1$ & 96 \\
10 & $\mathbf{5}$ & $10: 1$ & 94 \\
11 & $\mathbf{6}$ & $10: 1$ & 70 \\
12 & $\mathbf{1}$ & $20: 1$ & 95 \\
13 & $\mathbf{2}$ & $20: 1$ & 89 \\
14 & $\mathbf{3}$ & $20: 1$ & 98 \\
15 & $\mathbf{4}$ & $20: 1$ & 98 \\
16 & $\mathbf{5}$ & $20: 1$ & 96 \\
\hline
\end{tabular}

Soybean oil (AV $0.1 \mathrm{mg}_{\mathrm{KOH}} / \mathrm{g}_{\mathrm{oil}}$ ), catalyst:oil $0.10 \mathrm{~mol} \%, \mathrm{~T}=160{ }^{\circ} \mathrm{C}$, $2 \mathrm{~h}$

${ }^{\text {a }}$ Determined through NMR spectroscopy, error within $\pm 2 \%$

The data show that the methanol:oil ratio of $4: 1$ is in all cases insufficient to have an acceptable yield (entries 1-5) due to equilibrium limitation. NMR analysis [52] of the product reveals that the 1-monoglyceride (1-MG) is the most abundant non-transesterified component (Fig. 5) along with small amounts of the other monoglyceride (2-MG) and the two diglycerides (1,2-DG and 1,3-DG).

The equilibrium issues have been overcome achieving satisfactory yields on raising the methanol:oil ratio to $10: 1 \mathrm{~mol} /$ mol (entries 6-10) and consolidate at 20:1 mol:mol (entries 12-16). It has to be noted that similar yields were achieved for some catalysts by both methanol:oil ratios of 10:1 and 20:1 mol:mol. Although the higher ratio thermodynamically favours the conversion, the effect can be undetectable comparing very high conversions, since the values can fall within the experimental error limits. Interestingly, while the thermodynamics is enhanced by a higher amount of alcohol, the kinetics is slowed down by catalyst dilution. Probably, the action of both the phenomena affect the observed conversions, which in the end are the same within the experimental error bars.

Both dimer 1 and the acetate complexes 3-5 gave high and comparable yields, which allows drawing some preliminary conclusions. First, it is likely that dinuclear species $\mathbf{1}$ transforms into a corresponding mononuclear complex due to the presence of (small) amounts of FFA in the oil. In fact, it is known [53] that protic species, in this case $\mathrm{RCO}_{2} \mathrm{H}$, react with 1 according to the following stoichiometry (Eq. 1):

$\left[\mathrm{Fe}_{2}(\text { salen })_{2} \mathrm{O}\right](\mathbf{1})+2 \mathrm{RCO}_{2} \mathrm{H} \rightarrow 2\left[\mathrm{Fe}(\right.$ salen $\left.)\left(\mathrm{RCO}_{2}\right)\right]+\mathrm{H}_{2} \mathrm{O}$

Therefore, in the case of $\mathbf{1}$ the catalytic species is probably the monomer $\left[\mathrm{Fe}(\right.$ salen $\left.)\left(\mathrm{RCO}_{2}\right)\right]$, where $\mathrm{R}$ is the chain 

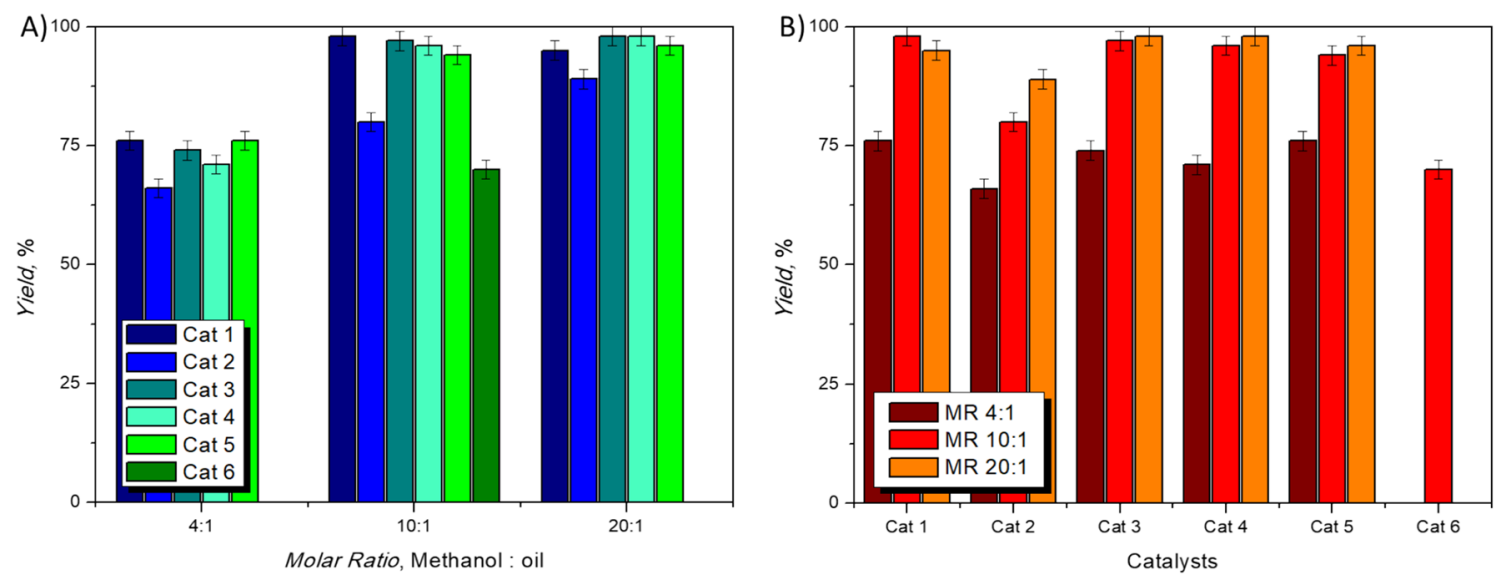

Fig. 4 A Results of Table 1 grouped by molar ratio. B Results of Table 1 grouped by catalyst

Fig. 5 Portion of the ${ }^{1} \mathrm{H}$ NMR spectrum of the biodiesel produced as in entry 3 of Table 1. For an example of full spectrum, see Figure S6

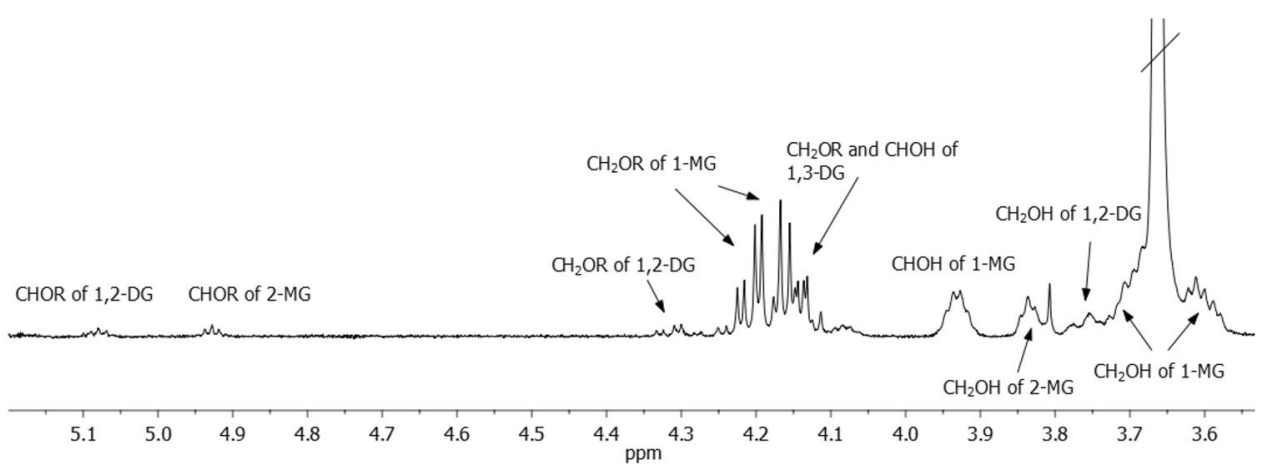

of a fatty acid, and therefore with stereoelectronic characteristics quite like complex $\mathbf{3}$.

It is also plausible that acetate is substituted for a fatty acid carboxylate in $\mathbf{3}, \mathbf{4}$ and $\mathbf{5}$ (Eq. 2):

$[\mathrm{Fe}($ salen $)(\mathrm{AcO})](\mathbf{3})+\mathrm{RCO}_{2} \mathrm{H} \rightarrow\left[\mathrm{Fe}(\right.$ salen $\left.)\left(\mathrm{RCO}_{2}\right)\right]+\mathrm{AcOH}$

The nearly identical activity of $\mathbf{3}, \mathbf{4}$ and $\mathbf{5}$ shows the absence of significant effects of the substitutions introduced in the basic salen structure. On the other hand, the yield significantly drops when acetate is substituted for a chloride in complex 2 (entries 2, 7, 13). In this case, the chloride ligand, that is a very weak Brønsted base, is likely not replaced by a carboxylate (see also Scheme 2), and this probably leads to an inadequate Lewis acidity of the complex which reduces its effectiveness. On the other hand, the cationic complex $\mathbf{6}$, in which the metal centre is more electron-poor, proved to be the least active (entry 11) for reasons yet to be established.

Catalysts 3 and $\mathbf{5}$ were selected for further testing considering the preliminary results obtained with soybean oil, even though it is possible that other varieties of oil may have a different impact on the performance. However, we relied on the results obtained with soybean oil to address the treatment of real matrices, because soybean oil is one
Table 2 Screening of the catalyst loading

\begin{tabular}{lllll}
\hline Entry & Catalyst & $\begin{array}{l}\text { Catalyst loading } \\
(\mathrm{mol} \%)\end{array}$ & $\begin{array}{l}\text { Time } \\
(\mathrm{h})\end{array}$ & $\begin{array}{l}\text { Yield }^{\mathrm{a}} \\
(\%)\end{array}$ \\
\hline 1 & $\mathbf{3}$ & 0.10 & 2 & 97 \\
2 & $\mathbf{3}$ & 0.050 & 2 & 82 \\
3 & $\mathbf{3}$ & 0.025 & 2 & 71 \\
4 & $\mathbf{5}$ & 0.10 & 2 & 94 \\
5 & $\mathbf{5}$ & 0.050 & 2 & 84 \\
6 & $\mathbf{5}$ & 0.025 & 2 & 65 \\
\hline
\end{tabular}

Soybean oil (AV $0.1 \mathrm{mg}_{\mathrm{KOH}} / \mathrm{g}_{\mathrm{oil}}$ ), methanol:oil molar ratio 10:1, $\mathrm{T}=160^{\circ} \mathrm{C}, 2 \mathrm{~h}$

${ }^{\text {a }}$ Determined through NMR spectroscopy, error within $\pm 2 \%$

of the most used worldwide, and therefore highly representative. Furthermore, the variables that make waste oils unique are mainly a consequence of the repeated processing to which they are subjected, rather than the different original composition of their fatty acids. Finally, catalysts $\mathbf{3}$ and $\mathbf{5}$ contain the simple hydroxybenzaldehyde, which is a convenient and economical building block, and can be both easily prepared in high yield. 
Table 3 Temperature and loading screening on simulated acidic oil

\begin{tabular}{llllllll}
\hline Entry & Catalyst & $\begin{array}{l}\text { Catalyst load- } \\
\text { ing }(\mathrm{mol} \%)\end{array}$ & Time (h) & $\begin{array}{l}\mathrm{T} \\
\left({ }^{\circ} \mathrm{C}\right)\end{array}$ & $\begin{array}{l}\text { Methanol:oil } \\
\text { ratio (mol:mol) }\end{array}$ & $\begin{array}{l}\text { Residual AV } \\
\left(\mathrm{mg}_{\mathrm{KOH}} / \mathrm{g}_{\mathrm{oil}}\right)\end{array}$ & $\begin{array}{l}\text { Yield }^{\mathrm{a}} \\
(\%)\end{array}$ \\
\hline 1 & $\mathbf{3}$ & 0.10 & 2 & 160 & $10: 1$ & 1.2 & 83 \\
2 & $\mathbf{3}$ & 0.10 & 2 & 180 & $10: 1$ & 1.3 & 90 \\
3 & $\mathbf{3}$ & 0.10 & 2 & 180 & $20: 1$ & 1.1 & 95 \\
4 & Iron(III) acetate & 0.10 & 2 & 180 & $20: 1$ & 1.7 & 38 \\
5 & $\mathbf{3}$ & 0.050 & 2 & 180 & $20: 1$ & 1.5 & 82 \\
6 & $\mathbf{3}$ & 0.050 & 4 & 180 & $20: 1$ & 1.3 & 90 \\
\hline
\end{tabular}

Soybean oil with added oleic acid (AV $\left.2.8 \mathrm{mg}_{\mathrm{KOH}} / \mathrm{g}_{\mathrm{oil}}\right)$

${ }^{a}$ Determined through NMR spectroscopy, error within $\pm 2 \%$

${ }^{\mathrm{b}}$ Determined by titration, error within \pm 0.1
The effect of the catalyst concentration was thus evaluated, reducing the loading to 0.050 and $0.025 \mathrm{~mol} \%$ (Table 2).

For both catalysts, this further reduction in loading led to an unsatisfactory conversion, thus confirming that $0.10 \mathrm{~mol} \%$ loading is the most suitable.

Starting from this data, the activity of $\mathbf{3}$ was first verified against a simulated used oil $\left(\mathrm{AV}=2.8 \mathrm{mg}_{\mathrm{KOH}} / \mathrm{g}_{\mathrm{oil}}\right)$ created by adding an appropriate amount of oleic acid to neutral, unused soybean oil (Table 3). The simulated acidic soybean oil was prepared by adding the appropriate amount of oleic acid to the fresh soybean oil to achieve an acidity appropriate to a typical WCO (AV $2.8 \mathrm{mg}_{\mathrm{KOH}} / \mathrm{g}_{\mathrm{oil}}$ ). Using $0.10 \mathrm{~mol} \%$ catalyst loading (entries $1-3$ ), the results show that slightly more rigorous conditions, such as a temperature of $180^{\circ} \mathrm{C}$ and a methanol:oil ratio $20: 1 \mathrm{~mol}: \mathrm{mol}$, are sufficient to achieve practically quantitative yield (entry 3 ). Under these conditions, the endogenous pressure reaches 24 bar. It is interesting to note that under these conditions the simple iron(III) acetate is nearly ineffective (entry 4). To check the possibility of further reducing the concentration of the catalyst, its loading was halved (entry 5) and a 4-h test (entry 6) was carried out, neither of which improves the performance of entry 3 .

The biodiesel yield under the best conditions of entry 3 (Table 3) was also followed in time for both $\mathbf{3}$ and $\mathbf{5}$, and the trend is shown in Fig. 6.

The two catalysts promote practically superimposable conversions, and the reactions are complete within two hours. The acid content is also significantly reduced, demonstrating that the catalysts exhibit acceptable activity towards esterification.

These optimized conditions were adopted in the treatment of two real vegetable oils coming from food waste. The first, WCO1, was a domestic oil, mildly used and with an acidity equal to $0.6 \mathrm{mg}_{\mathrm{KOH}} / \mathrm{g}_{\text {oil }}$. The second, WCO2, was instead an oil from industrial catering, subject to repeated thermal stresses, and with a high acidity content

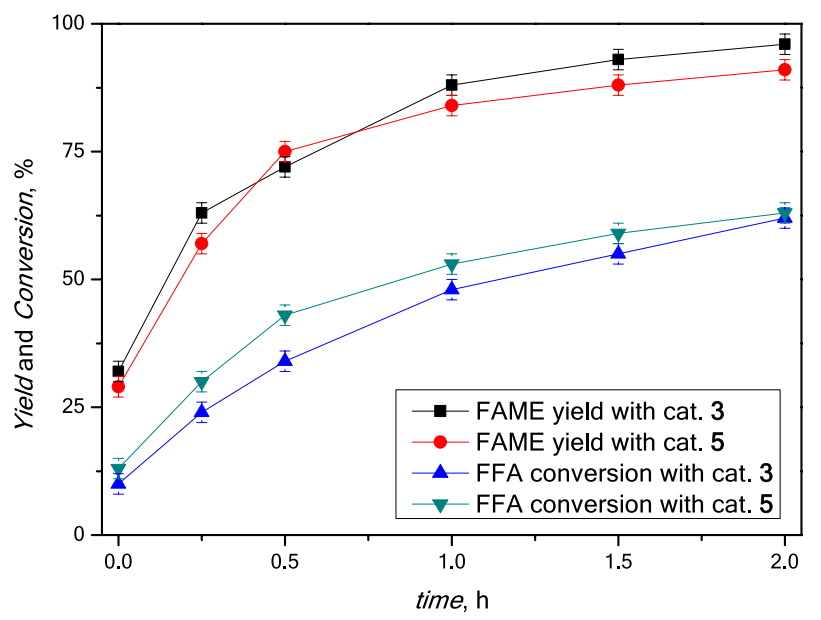

Fig. 6 Biodiesel yield and FFA conversion vs time plot, using catalysts 3 and $\mathbf{5}$. Conditions as Table 3 entry 3

Table 4 Performance of $\mathbf{3}$ with fresh and waste cocking oils with comparable acidity values

\begin{tabular}{lllll}
\hline Entry & Substrate & $\begin{array}{l}\text { Initial AV } \\
\left(\mathrm{mg}_{\mathrm{KOH}} /\right. \\
\left.\mathrm{g}_{\mathrm{oil}}\right)\end{array}$ & $\begin{array}{l}\text { Residual } \\
\mathrm{AV}^{\mathrm{b}}\left(\mathrm{mg}_{\mathrm{KOH}} /\right. \\
\left.\mathrm{g}_{\mathrm{oil}}\right)\end{array}$ & $\begin{array}{l}\text { Yield }^{\mathrm{a}} \\
(\%)\end{array}$ \\
\hline 1 & Neutral soybean oil & 0.1 & $<0.1$ & $>98$ \\
2 & WCO1 & 0.6 & $<0.5$ & 90 \\
3 & $\begin{array}{l}\text { Simulated acidic soy- } \\
\text { bean oil }\end{array}$ & 2.8 & 1.1 & 95 \\
4 & WCO2 & 2.8 & 1.3 & 85 \\
\hline
\end{tabular}

Cat 3:oil $0.10 \mathrm{~mol} \%$, methanol:oil molar ratio $20: 1, \mathrm{~T}=180{ }^{\circ} \mathrm{C}, 2 \mathrm{~h}$

${ }^{\text {a }}$ Determined through NMR spectroscopy, error within $\pm 2 \%$

$\left(\mathrm{AV}=2.8 \mathrm{mg}_{\mathrm{KOH}} / \mathrm{g}_{\mathrm{oil}}\right)$. The two oils were used as received, after a single filtration through a sieve to eliminate any suspended solid particles. The results (Table 4) show that catalyst $\mathbf{3}$ is still active and performing in both cases, allowing a biodiesel yield of $90 \%$ with WCO1 (entry 2) 
and $85 \%$ with WCO2 (entry 4). Comparing these results with those obtained from fresh oils with comparable AV values (entries 1 and 3), can be seen that the thermal treatment, or any possible poisoning pollutants produced by it, slightly affect the catalyst activity.

In summary, it can be realised how the different nature of the oils is reflected in the performance of the catalysts. High conversion of neutral oil is achieved already at a temperature of $160{ }^{\circ} \mathrm{C}(97 \%$, entry 1 of Table 2$)$. In the same conditions, the simulated acidified oil is less converted (83\%, entry 1 of Table 3 ). This oil requires higher temperature $\left(180^{\circ} \mathrm{C}\right)$ and higher methanol:oil molar ratio (20:1 mol:mol) to achieve satisfactory conversions $(95 \%$, entry 3 of Table 3 ). Under these conditions, the real matrices $\mathrm{WCO} 1$ and $\mathrm{WCO} 2$ are even more resistant towards transesterification, to an extent that depends on both thermal stress and acidity value (entries 2 and 4 of Table 4 ).

The iron content of various fractions (exhausted oils as well as the corresponding biodiesel and glycerol) was quantified by ICP-MS analysis (Table 5).

Iron was not detected in the initial oil samples, so all iron observed in the products derives from the catalyst employed. Interestingly, the biodiesel fraction contains only $~ 10-14 \mu \mathrm{g} / \mathrm{g}$ of Fe.

Although no concentration limit values have been specified for iron content in biodiesel, its presence could have some negative effects for the engine system [54]. However, small iron and zinc contaminations in biodiesel are almost ubiquitous due to the use of metallic fuel tanks for its storage and transportation [55]. Rudrigues et al. [54] investigated the iron concentration for commercial pure biodiesel (B100) derived from different biological feedstocks finding a value of about 5-10 ppm. Therefore, the final concentration of iron in the biodiesel produced with the proposed catalyst is commonly found in commercial samples and may not need to be removed from the product.

Table 5 Iron quantification by ICP-MS in biodiesel and glycerol from exhausted oils

\begin{tabular}{lll}
\hline Sample & Oil & $\begin{array}{l}\text { Mean } \pm \text { stand- } \\
\text { ard deviation } \\
(\mu \mathrm{g} / \mathrm{g})\end{array}$ \\
\hline WCO1 & Domestic oil & $<0.001$ \\
$\mathrm{WCO} 2$ & Industrial catering & $<0.001$ \\
Biodiesel WCO1 & Domestic oil & $10.1 \pm 0.5$ \\
Biodiesel WCO2 & Industrial catering & $14.2 \pm 0.6$ \\
Glycerol WCO1 & Domestic oil & $61.3 \pm 3.0$ \\
Glycerol WCO2 & Industrial catering & $24.1 \pm 1.5$ \\
\hline
\end{tabular}

\section{Conclusion}

This work demonstrates that iron(III) complexes containing salen ligands are effective catalysts for the transesterification of vegetable oils, and especially WCO, to produce biodiesel. The study initially envisaged a screening of both dimeric and monomeric catalysts, with different substituents on salen and diverse anions, coordinating (chloride and acetate) or non-coordinating (tetrafluoroborate). This structure-activity study allowed to identify the acetato-species as the most performing. A possible reaction pathway involves the activation of the carbonyl group by coordination to the metal centre, and the intervention of a base (acetate) in the step of the product release. The beneficial presence of the salen ligand was also demonstrated by comparing the activity of the complexes with that of simple iron(III) acetate. In optimized conditions $\left(180{ }^{\circ} \mathrm{C}, 2 \mathrm{~h}\right.$, methanol:oil ratio of $\left.20: 1 \mathrm{~mol} / \mathrm{mol}\right)$ two waste cooking oils were converted in yields up to $90 \%$ by using simple salen iron(III) acetate.

Interestingly, the low catalyst loading made it possible to recover biodiesel with a residual iron content of only a few ppm, a value comparable to that found in biodiesels from other sources. This opens the way to the design of processes in which exhausted feedstock can be transformed into biofuels in a single step, and without the inconvenience of subsequent catalyst separation, thus bypassing the possible disadvantages of homogeneous catalysis. The modularity of the catalyst synthesis will enable further fine-tuning for improved activity.

Supplementary Information The online version contains supplementary material available at https://doi.org/10.1007/s10562-022-03948-x.

Acknowledgements Roberto Esposito and Gabriella Pinto thank European Union and MIUR for funding through PON-AIM project code E61G19000090002, proposal code AIM1829571-1. The authors thank Miss Immacolata Manco for technical assistance.

Open Access This article is licensed under a Creative Commons Attribution 4.0 International License, which permits use, sharing, adaptation, distribution and reproduction in any medium or format, as long as you give appropriate credit to the original author(s) and the source, provide a link to the Creative Commons licence, and indicate if changes were made. The images or other third party material in this article are included in the article's Creative Commons licence, unless indicated otherwise in a credit line to the material. If material is not included in the article's Creative Commons licence and your intended use is not permitted by statutory regulation or exceeds the permitted use, you will need to obtain permission directly from the copyright holder. To view a copy of this licence, visit http://creativecommons. org/licenses/by/4.0/. 


\section{References:}

1. Climent MJ, Corma A, Iborra S (2014) Conversion of biomass platform molecules into fuel additives and liquid hydrocarbon fuels. Green Chem 16:516-547. https://doi.org/10.1039/C3GC4 1492B

2. Aresta M, Dibenedetto A, Dumeignil F (2015) Biorefineries. De Gruyter, Boston, pp v-vi

3. Ramos M, Dias APS, Puna JF, Gomes J, Bordado JC (2019) Biodiesel production processes and sustainable raw materials. Energies 12:4408. https://doi.org/10.3390/en12234408

4. IEA, Global biofuel production in 2019 and forecast to 2025 . https://www.iea.org/data-and-statistics/charts/global-biofuelproduction-in-2019-and-forecast-to-2025

5. Esposito R, Cucciolito ME, D'Amora A, Di Guida R, Montagnaro F, Ruffo F (2017) Highly efficient iron(III) molecular catalysts for solketal production. Fuel Process Technol 167:670-673. https://doi.org/10.1016/j.fuproc.2017.08.018

6. Esposito R, Raucci U, Cucciolito ME, Di Guida R, Scamardella C, Rega N, Ruffo F (2019) Iron(III) complexes for highly efficient and sustainable ketalization of glycerol: a combined experimental and theoretical study. ACS Omega 4:688-698. https:// doi.org/10.1021/acsomega.8b02546

7. Taddeo F, Esposito R, Russo V, Di Serio M (2021) Kinetic modeling of solketal synthesis from glycerol and acetone catalyzed by an iron(III) complex. Catalysts 11:83. https://doi.org/ 10.3390/catal11010083

8. Felizardo P, Correia MJ, Raposo I, Mendes JF, Berkemeier R, Bordado JM (2006) Production of biodiesel from waste frying oils. Waste Manag 26:487-494. https://doi.org/10.1016/j.wasman.2005.02.025

9. Zheng S, Kates M, Dubé MA, McLean DD (2006) Acid-catalyzed production of biodiesel from waste frying oil. Biomass Bioenerg 30:267-272. https://doi.org/10.1016/j.biombioe.2005. 10.004

10. Predojević ZJ (2008) The production of biodiesel from waste frying oils: a comparison of different purification steps. Fuel 87:3522-3528. https://doi.org/10.1016/j.fuel.2008.07.003

11. Benessere V, Cucciolito ME, Esposito R, Lega M, Turco R, Ruffo F, Di Serio M (2016) A novel and robust homogeneous supported catalyst for biodiesel production. Fuel 171:1-4. https://doi.org/10. 1016/j.fuel.2015.12.040

12. Fonseca JM, Teleken JG, de Cinque Almeida V, da Silva C (2019) Biodiesel from waste frying oils: methods of production and purification. Energy Convers Manag 184:205-218. https://doi.org/10. 1016/j.enconman.2019.01.061

13. Khodadadi MR, Malpartida I, Tsang C-W, Lin CSK, Len C (2020) Recent advances on the catalytic conversion of waste cooking oil. Mol Catal 494:111128. https://doi.org/10.1016/j.mcat.2020. 111128

14. United Nations Sustainable Development Goals n. 12. https://sdgs. un.org/goals

15. Jalkh R, El-Rassy H, Chehab GR, Abiad MG (2017) Assessment of the physico-chemical properties of waste cooking oil and spent coffee grounds oil for potential use as asphalt binder rejuvenators. Waste Biomass Valor 9:2125-2132. https://doi.org/10.1007/ s12649-017-9984-z

16. Rizwanul Fattah IM, Ong HC, Mahlia TMI, Mofijur M, Silitonga AS, Rahman SMA, Ahmad A (2020) State of the art of catalysts for biodiesel production. Front Energy Res. https://doi.org/10. 3389/fenrg.2020.00101

17. Di Serio M, Tesser R, Dimiccoli M, Cammarota F, Nastasi M, Santacesaria E (2005) Synthesis of biodiesel via homogeneous Lewis acid catalyst. J Mol Catal A 239:111-115. https://doi.org/ 10.1016/j.molcata.2005.05.041
18. Changmai B, Vanlalveni C, Ingle AP, Bhagat R, Rokhum L (2020) Widely used catalysts in biodiesel production: a review. RSC Adv 10:41625-41679. https://doi.org/10.1039/d0ra07931f

19. Singh D, Sharma D, Soni SL, Sharma S, Kumar Sharma P, Jhalani A (2020) A review on feedstocks, production processes, and yield for different generations of biodiesel. Fuel 262:116553. https:// doi.org/10.1016/j.fuel.2019.116553

20. Melchiorre M, Cucciolito ME, Di Serio M, Ruffo F, Tarallo O, Trifuoggi M, Esposito R (2021) Homogeneous catalysis and heterogeneous recycling: a simple $\mathrm{Zn}$ (II) catalyst for green fatty acid esterification. ACS Sustain Chem Eng 9:6001-6011. https://doi. org/10.1021/acssuschemeng.1c01140

21. Esposito R, Melchiorre M, Annunziata A, Cucciolito ME, Ruffo F (2020) Emerging catalysis in biomass valorisation: simple $\mathrm{Zn}$ (II) catalysts for fatty acids esterification and transesterification. ChemCatChem 12:5858-5879. https://doi.org/10.1002/cctc. 202001144

22. Melchiorre M, Amendola R, Benessere V, Cucciolito ME, Ruffo F, Esposito R (2020) Solvent-free transesterification of methyl levulinate and esterification of levulinic acid catalyzed by a homogeneous iron(III) dimer complex. Mol Catal 483:110777. https:// doi.org/10.1016/j.mcat.2020.110777

23. Dhawane SH, Al-Sakkari EG, Halder G (2019) Kinetic modelling of heterogeneous methanolysis catalysed by iron induced on microporous carbon supported catalyst. Catal Lett 149:35083524. https://doi.org/10.1007/s10562-019-02905-5

24. Olubunmi BE, Karmakar B, Aderemi OM, G AU, Auta M, Halder G (2020) Parametric optimization by Taguchi L9 approach towards biodiesel production from restaurant waste oil using $\mathrm{Fe}$ supported anthill catalyst. J Environ Chem Eng 8:104288. https:// doi.org/10.1016/j.jece.2020.104288

25. Benessere V, Cucciolito ME, Dal Poggetto G, Di Serio M, Granados ML, Ruffo F, Vitagliano A, Vitiello R (2014) Strategies for immobilizing homogeneous zinc catalysts in biodiesel production. Catal Commun 56:81-85. https://doi.org/10.1016/j.catcom.2014. 07.011

26. Benessere V, Cucciolito ME, De Santis A, Di Serio M, Esposito R, Melchiorre M, Nugnes F, Paduano L, Ruffo F (2019) A sustainable process for the production of varnishes based on Pelargonic acid esters. J Am Oil Chem Soc 96:443-451. https://doi.org/10. 1002/aocs. 12200

27. Melchiorre M, Benessere V, Cucciolito ME, Melchiorre C, Ruffo F, Esposito R (2020) Direct and solvent-free oxidative cleavage of double bonds in high-oleic vegetable oils. ChemistrySelect 5:1396-1400. https://doi.org/10.1002/slct.201903516

28. Commission Implementing Regulation (EU) 2016/1227 of 27 July 2016 amending Regulation (EEC) No 2568/91 on the characteristics of olive oil and olive-residue oil and on the relevant methods of analysis. http://data.europa.eu/eli/reg_impl/2016/1227/oj

29. Nemec I, Herchel R, Šilha T, Trávníček Z (2014) Towards a better understanding of magnetic exchange mediated by hydrogen bonds in $\mathrm{Mn}$ (iii)/Fe(iii) salen-type supramolecular dimers. Dalton Trans 43:15602-15616. https://doi.org/10.1039/C4DT02025A

30. Pfeiffer P, Breith E, Lübbe E, Tsumaki T (1933) Tricyclische orthokondensierte Nebenvalenzringe. Justus Liebigs Ann Chem 503:84-130. https://doi.org/10.1002/jlac.19335030106

31. Wang J, Jian F, Zhuang R, Qiao Y (2012) A new $\mu$-oxo dimer iron(III) complex: synthesis, characterization, and electrocatalysis. Synth React Inorg, Met-Org, Nano-Met Chem 42:711-715. https://doi.org/10.1080/15533174.2011.615779

32. Sheikhshoaie I, Khabazzadeh H, Saeid-Nia S (2009) Iron(III) (salen) $\mathrm{Cl}$ as an efficient catalyst for synthesis of bis(indolyl) methanes. Transit Met Chem 34:463-466. https://doi.org/10.1007/ s11243-009-9217-9

33. Mukherjee RN, Abrahamson AJ, Patterson GS, Stack TDP, Holm RH (1988) A new class of (N, N'-bis(salicylideneamino)ethanato) 
iron(ii) complexes - 5-coordinate [Feii(Salen)L]--preparation, properties, and mechanism of electron-transfer reactions. Inorg Chem 27:2137-2144. https://doi.org/10.1021/ic00285a026

34. Driscoll OJ, Hafford-Tear CH, McKeown P, Stewart JA, KociokKöhn G, Mahon MF, Jones MD (2019) The synthesis, characterisation and application of iron(III)-acetate complexes for cyclic carbonate formation and the polymerisation of lactide. Dalton Trans 48:15049-15058. https://doi.org/10.1039/C9DT03327K

35. La Mar GN, Eaton GR, Holm RH, Walker FA (2002) Proton magnetic resonance investigation of antiferromagnetic oxo-bridged ferric dimers and related high-spin monomeric ferric complexes. J Am Chem Soc 95:63-75. https://doi.org/10.1021/ja00782a012

36. Gullotti M, Casella L, Pasini A, Ugo R (1977) Optically active complexes of Schiff bases. Part 3. Complexes of iron(III) with quadridentate Schiff bases derived from salicylaldehyde. J Chem Soc Dalton Trans 2:339-345. https://doi.org/10.1039/DT977 0000339

37. Laurikenas A, Barkauskas J, Reklaitis J, Niaura G, Baltrūnas D, Kareiva A (2016) Formation peculiarities of iron(III) acetate potential precursor for iron metal-organic frameworks (MOFs). Lith J Phys 56:35-41. https://doi.org/10.3952/physics.v56i1.3274

38. Altomare A, Burla MC, Camalli M, Cascarano GL, Giacovazzo C, Guagliardi A, Moliterni AGG, Polidori G, Spagna R (1999) SIR97: a new tool for crystal structure determination and refinement. J Appl Crystallogr 32:115-119. https://doi.org/10.1107/ S0021889898007717

39. Sheldrick G (2015) Crystal structure refinement with SHELXL. Acta Crystallogr C 71:3-8. https://doi.org/10.1107/S205322961 4024218

40. Farrugia L (2012) WinGX and ORTEP for windows: an update. J Appl Crystallogr 45:849-854. https://doi.org/10.1107/S0021 889812029111

41. Macrae CF, Bruno IJ, Chisholm JA, Edgington PR, McCabe P, Pidcock E, Rodriguez-Monge L, Taylor R, van de Streek J, Wood PA (2008) Mercury CSD 2.0-new features for the visualization and investigation of crystal structures. J Appl Crystallogr 41:466-470. https://doi.org/10.1107/S0021889807067908

42. Horikawa R, Fujimoto C, Yazaki R, Ohshima T (2016) mu-Oxodinuclear-iron(III)-catalyzed O-selective acylation of aliphatic and aromatic amino alcohols and transesterification of tertiary alcohols. Chem Eur J 22:12278-12281. https://doi.org/10.1002/ chem. 201602801

43. Chino M, Leone L, Maglio O, D’Alonzo D, Pirro F, Pavone V, Nastri F, Lombardi A (2017) A de novo heterodimeric due Ferri protein minimizes the release of reactive intermediates in dioxygen-dependent oxidation. Angew Chem Int Ed 56:15580-15583. https://doi.org/10.1002/anie.201707637

44. Abd El Sater M, Jaber N, Schulz E (2019) Chiral Salen complexes for asymmetric heterogeneous catalysis recent examples for recycling and cooperativity. ChemCatChem 11:3662-3687. https:// doi.org/10.1002/cctc.201900557
45. Liu G, Arif AM, Bruenger FW, Miller SC (1999) A new linear polymer chain iron complex; synthesis, crystal and molecular structural characterization of catena- $\mu$-acetato-[ $\left[\mathrm{NN}^{\prime}\right.$ ethylenebis(salicylaldiminato)]iron(III). Inorg Chim Acta 287:109-112. https://doi.org/10.1016/S0020-1693(98)00399-5

46. Dusek M, Petricek V, Kamenicek J, Sindelar Z (1992) Structure of [mu]-(tetraphthalato)-bis[N, N'-ethylenebis(salicylaldiminato) iron(III)]. Acta Crystallogr C 48:1579-1582. https://doi.org/10. 1107/S0108270192000982

47. Pap JS, Matuz A, Baráth G, Kripli B, Giorgi M, Speier G, Kaizer J (2012) Bio-inspired flavonol and quinolone dioxygenation by a non-heme iron catalyst modeling the action of flavonol and 3-hydroxy-4(1H)-quinolone 2,4-dioxygenases. J Inorg Biochem 108:15-21. https://doi.org/10.1016/j.jinorgbio.2011.11.013

48. Sutradhar M, Roy Barman T, Drew MGB, Rentschler E (2013) Mononuclear and tetranuclear Fe(III) complexes with two different types of N, O donor Schiff base ligands. J Mol Struct 1041:44 49. https://doi.org/10.1016/j.molstruc.2013.02.035

49. Bäumler C, Bauer C, Kempe R (2020) The synthesis of primary amines through reductive amination employing an iron catalyst. Chemsuschem 13:3110-3114. https://doi.org/10.1002/cssc.20200 0856

50. Wolzak LA, van der Vlugt JI, van den Berg KJ, Reek JNH, Tromp M, Korstanje TJ (2020) Titanium-catalyzed esterification reactions: beyond Lewis acidity. ChemCatChem 12:5229-5235. https://doi.org/10.1002/cctc.202000931

51. Wolzak LA, Hermans JJ, de Vries F, van den Berg KJ, Reek JNH, Tromp M, Korstanje TJ (2021) Mechanistic elucidation of monoalkyltin(iv)-catalyzed esterification. Catal Sci Technol 11:3326-3332. https://doi.org/10.1039/D1CY00184A

52. Nieva-Echevarría B, Goicoechea E, Manzanos MJ, Guillén MD (2014) A method based on 1H NMR spectral data useful to evaluate the hydrolysis level in complex lipid mixtures. Food Res Int 66:379-387. https://doi.org/10.1016/j.foodres.2014.09.031

53. Wollmann RG, Hendrickson DN (1978) Reaction of .mu.-oxobridged iron(III) complexes with organic acids: a characterization of the products. Inorg Chem 17:926-930. https://doi.org/10.1021/ ic50182a026

54. Rodrigues SSM, Lima AS, Teixeira LSG, Korn MGA, Santos JLM (2014) Determination of iron in biodiesel based on fluorescence quenching of CdTe quantum dots. Fuel 117:520-527. https://doi.org/10.1016/j.fuel.2013.09.045

55. Korn MGA, Santos DSS, Welz B, Vale MGR, Teixeira AP, Lima DC, Ferreira SLC (2007) Atomic spectrometric methods for the determination of metals and metalloids in automotive fuels-a review. Talanta 73:1-11. https://doi.org/10.1016/j.talanta.2007. 03.036

Publisher's Note Springer Nature remains neutral with regard to jurisdictional claims in published maps and institutional affiliations.

\section{Authors and Affiliations}

\section{Massimo Melchiorre ${ }^{1,2} \cdot$ Angela Amoresano $^{1}$ • Peter H. M. Budzelaar ${ }^{1} \cdot$ Maria E. Cucciolito $^{1,3} \cdot$ Fabio Mocerino $^{1}$. Gabriella Pinto ${ }^{1}$ - Francesco Ruffo ${ }^{1,3}$ - Angela Tuzi ${ }^{1} \cdot$ Roberto Esposito ${ }^{1,3}$}

1 Dipartimento di Scienze Chimiche, Università di Napoli Federico II, Complesso Universitario di Monte S. Angelo, via Cintia 21, 80126 Naples, Italy

2 ISUSCHEM, piazza Carità 32, 80134 Naples, Italy
3 Consorzio Interuniversitario di Reattività Chimica e Catalisi (CIRCC), via Celso Ulpiani 27, 70126 Bari, Italy 